\title{
Gravidade do distúrbio fonológico: julgamento perceptivo e porcentagem de consoantes corretas $* * * *$
}

\author{
Severity of phonological disorders: perceptual judgment and \\ percentage of correct consonants
}

\author{
Haydée Fiszbein Wertzner* (hfwertzn@usp.br) \\ Luciana Amaro** \\ Suzana Sumie Teramoto***
}

*Fonoaudióloga. Professora LivreDocente do Curso de Fonoaudiologia do Departamento de Fisioterapia,

Fonoaudiologia e Terapia Ocupacional da Faculdade de Medicina da Universidade de São Paulo (FMUSP). Coordenadora do Laboratório de Investigação Fonoaudiológica em Fonologia do Curso de Fonoaudiologia do Departamento de Fisioterapia, Fonoaudiologia e Terapia Ocupacional da FMUSP.

**Fonoaudióloga. Mestranda pelo Departamento de Semiótica e

Linguística da Faculdade de Filosofia Letras e Ciências Sociais da USP.

***Fonoaudióloga.

*****Trabalho Realizado no Laboratório de Investigação

Fonoaudiológica em Fonologia. Curso de Fonoaudiologia do Departamento de Fisioterapia, Fonoaudiologia e Terapia Ocupacional da FMUSP.

Artigo de Pesquisa

Artigo Submetido a Avaliação por Pares

Conflito de Interesse: não

Recebido em 1.08.2003.

Revisado em 10.11.2003; 30.08.2004; 14.12.2004.

Aceito para Publicação em 29.12.2004.

\begin{abstract}
Background: phonological disorder. Aim: to apply the percentage of correct consonant (PCC) index and to verify the correlation between this index and the one applied perceptually by judges. Method: the PCC index of 50 phonological disordered subjects was calculated, after 60 judges heard the phonological tests for each subject and perceptually attributed the severity. Results: the PCC index varied from $40 \%$ to $98 \%$, with the predominant classification of the population in the mild and mild-moderate levels. Conclusion: a correlation between the perceptual judgment and the PCC indexes exists.
\end{abstract}

Key Words: Language Development Disorders; Assessment; Diagnosis; Severity.

\section{Resumo}

Tema: distúrbio Fonológico. Objetivo: aplicar o índice de gravidade de Porcentagem de Consoantes Corretas (PCC) e verificar a correlação entre este índice e o aplicado perceptivamente pelos juízes. Método: calculou-se o índice de gravidade PCC de 50 sujeitos diagnosticados com distúrbio fonológico, após 60 juízes ouviram as provas de fonologia de cada sujeito e julgaram perceptivamente a gravidade. Resultado: o índice PCC aplicado aos sujeitos obteve uma variação entre $40 \%$ e $98 \%$, com uma classificação predominante da população nos graus leve e levemente moderado. Conclusão: existe correlação entre o julgamento perceptivo dos juizes e os valores do índice PCC.

Palavras-Chave: Transtornos do Desenvolvimento da Linguagem; Avaliação; Diagnóstico; Gravidade.

WERTZNER, H. F.; AMARO, L.; TERAMOTO, S. S. Severity of phonological disorders - perceptual judgment and percentage of correct consonants (original title: a Gravidade do distúrbio fonológico - julgamento perceptivo e porcentagem de consoantes corretas). Pró-Fono Revista de Atualização Científica, Barueri (SP), v. 17, n. 2, p. 185-194, maio-ago. 2005. 


\section{Introduction}

Studies indicate that among the speech and language disorders, the phonological disorder is of great occurrence in the children's population (Shriberg e Kwiatkowski, 1994; Gierut, 1998).Thus, there is a major concern with children's speech and language that, many times, become hard to understand. It is recommended that the phonological disorder must be detected during infancy, once very often, subjects with phonological disorder have phonological sensitivity alteration and, later, when they are exposed to literacy, they can have phonological awareness disorder, affecting the learning of reading and writing (Gierut,1998; Wagner et al., 1999).

The phonological disorder is defined as a speech disorder characterized by an inadequate sound production and use of phonological rules of a language, regarding the sound distribution and the type of syllable, resulting in the collapse of phonemic contrasts and affecting the meaning of the message. The cause of the phonological disorder is unknown and there is a varying degree of severity and speech intelligibility (Peña-Brooks, Hedge, 2000; Wertzner, 2002).

For the diagnosis of the phonological disorder it is necessary, besides the identification of the phonetic inventory of the child, to analyze the syllabic structures verified in the child's speech sample and the sound distribution in these structures as well as in the words, pointing out the phonological rules used by him/her and the contrasts that he/she maintains in the speech.

From the linguistic point of view, the literature indicates that children with phonological disorders have similar speech characteristics, such as reduced sound inventory, simple syllabic structures, and use of a limited number of phonological processes, usually similar to a normal child, and some use idiosyncratic processes. Children with phonological disorder present a different sequence of phonological acquisition when compared with a normal child, and have difficulty in phonological contrast maintenance, showing a great variability in his/her production (Stoel-Gammon e Dunn, 1985).

Furthermore, Fey (1992) states that a phonological acquisition deficit suggests potential difficulties in several levels, including phonetic discrimination, phonological contrasts recognition and its representation in lexicon, changes of standard sounds of speech through the inadequate use of phonological rules, and imprecise articulation, among other factors.

Lamprecht (1995), points out that the child with phonological disorder has particular characteristics, such as: higher incidence of phonological processes than a child with normal development; the phonological processes may persist for a longer time; the phonological processes from the beginning of the acquisition may occur at the same time as the latter ones, or be suppressed later; and higher co-occurrence of several processes at the same moment.

According to Bowen (1998), the phonological system of children with phonological disorders is similar to the normal children's one, and in some cases, there are phonological processes that are not observed regularly in development. It is believed that each child develops language in a particular way and with a great individual variation, although it is expected a certain peculiar sequence and speed in the phonological development.

The classification of the severity of phonological disorders is a very discussed matter in the literature.

According to Hodson and Paden (1981), the severity of a phonological disorder varies according to the number and the quality of phonological processes used, and the level of speech intelligibility.

Some studies demonstrate the concern with the severity classification, such as the Shriberg and Kwiatkowski's (1982) study that points out the necessity of procedures to quantify the severity and the impact of the communication disorders in the diagnostic classification system, in the intervention planning directed to the child's difficulties, and in the therapeutic control.

Shriberg and Kwiatkowski (1982) used the Percentage of Correct Consonant index (PCC), calculated from spontaneous speech samples. This measure is one of the components of the diagnostic classification system described by the authors and reflect the severity of the phonological disorder in an increasing scale.

The PCC index values includes four degrees of severity: mild, corresponding to more than $85 \%$ of correct consonants; mild-moderate, varying between $85 \%$ and $65 \%$; moderate-severe, varying between 50 and $65 \%$; and severe, below $50 \%$.

In this same study, the authors (op. cit) evalueted 30 samples of continuous speech of children from 3 to 9 years-old. The PCC index and 
the perceptual judgment of the severity degree were applied. It was verified that there is concordance and stability in the perceptual judgment, besides the existing corelation between the judgment and the PCC index.

In another study, Shriberg et al. (1986) analised 114 subjects with phonological disorder regarding the severity (measured by PCC) and the speech intelligibility. They concluded that the PCC values for small children with phonological delay were consistently associated with the age, and approximatelly $80 \%$ of the uttered words were inintelligible.

In 1991, Hodson and Paden proposed a severity classification applying the concept that the speech disorders are part of a continuum. They considered that:

. the profound degree is characterized by many omissions and some substitutions;

. the severe one presents many substitutions and some omissions;

. the moderate has some characteristics of the mild and the severe degrees; and the mild shows sibilant distortions and slight changes in the place and manner of articulation.

Hodson and Paden (1991) suggested that the use of the Phonological Disorder Score index (PDS) would indicate the severity. This measure is based on the frequency of occurrence of phonological processes chosen by the child and is calculated from the production of isolated words. The authors performed a comparative study between the severity measures of PCC, PDS and the listener's perception. Twenty children from 5 to 9 years of age with varying degrees of severity took part in this study. Each child was asked to tell a story based on sequenced cards and the authors used between 2 minutes, 30 seconds and 3 minutes, 30 seconds of the spontaneous speech. The results indicated a high correlation between the listener's evaluation and the PCC and the PDS in isolated words, suggesting that the standardization of isolated words as the result of a test can be worthwhile and clinically used as an instrument in the phonological disorder evaluation.

Garret and Moran (1992) compared the severity of the phonological disorder in 20 children through five measures: the phonological disorder score (PDS), the Percentage of Correct Consonant (PCC) in spontaneous speech and in isolated words, and the perceptive analysis of two groups of judges (one of them comprised by 10 graduated in elementary education and the other by 10 speech pathologists). The judges were instructed to choose the pertinent severity degree of each child's disorder, from 1 (mild) to 7 (severe). Likewise in the Shriberg e Kwiatkowski's study (1982), it was found a high correlation between the indexes and the perceptual judgment of the judges.

Morrison and Shriberg (1992), found statistical differences between the articulatory precision profiles measured with the PCC index for the articulation tests, in isolated words and in continuous speech. All linguistic levels were analysed, including the precision, the phonological processes, the individual phonemes, the types of errors, the word positioning, and the allophones. The stable sounds were frequently produced with higher precision in spontaneous speech, while the emergential sounds presented higher precision as a response for the articulation tests' stimuli. In general, the continuous speech seemed to be more associated with elimination errors, specially of consonants in the final position of the word, and with the increase of errors involving groups and atonic syllables.

Another phonological severity measure is the "Process Density Index" (PDI) (Edwards, 1992), which is the mean of phonological processes in one word. The PDI is an inverse measure from PCC, since the $\mathrm{PCC}$ is a correct production measure, while the PDI is based on incorrect productions. The PCC is a binary measure, based on the simple distinction between correct/incorrect; on the contrary, the PDI considers the fact that a single incorrect sound can result in the applying of one or more processes. Although it is necessary more refinements and more tests, the PDI can be seen as a measure of great clinic potential for phonological severity and/or intelligibility (Edwards, 1992).

Applying the PCC index in children with phonological disorder, Shriberg and Kwiatkowski (1994) observed that over half of the children (54\%) presented mild-moderate degree of severity, approximatelly one third of them (32\%) presented moderate-severe degree, and the rest of them (10 to $15 \%$ ) presented mild and severe degrees of severity.

Shriberg et al. (1997) proposed a revision of the PCC, aiming at a better adaptation for the diferential diagnosis of the phonological disorders' subtypes. Accordng to the considered type of error, they suggested: PCC - common or uncommon distortions, omissions and substitutions are considered as errors; Adjusted PCC - common distortions are not considered as 
errors; and Revised PCC - does not accept any type of distortion as error. To test these indexes, the authors used 836 tapes of subjects from 3 to 40 years of age, with normal or altered speech, aiming at a diagnostic classification based on the instrument of Speech Disorder Classification System (SDCS). The study pointed that the PCC$\mathrm{R}$ is the best articulatory competence measure for children from 3 to 8 years, since it provides a better separation between children with normal speech acquisition and those with late speech development, and it indicates only the omissions and substitutions errors. The authors observed that children with normal acquisition presented $37 \%$ of elimination and substitution errors, while children with late speech presented $82 \%$ of these types of errors.

In a study carried out by Wertzner et al. (2001) with 22 children from 4:5 to 6:1 years of age, there was only one child with a severe degree of phonological disorder $(4,5 \%), 8$ subjects $(36,3 \%)$ presented mild-moderate degree, 7 subjects $(27,2 \%)$ presented moderate-severe degree, and 6 subjects presented mild degree.

The severity categories of PCC (mild, mildmoderate, moderate-severe, and severe) proposed by Shriberg and Kwiatkowski (1982) was designed for the English languge. For its aplication in the Portuguese language, further studies are necessary. In this regard, some studies have been carried out with normal speech development children (Dias and Wertzner, 2000; Wertzner and Galea, 2002) and with children with phonological disorder (Wertzner et al., 2001: Wertzner, 2002) using the PCC classification.

There are some studies in the literature about the most prevalent age or gender in phonological disorder. Among them, Shriberg et al. (1999) studied 6:00 years-old children with phonological disorders and verified that the prevalence rate of phonological disorder at this age was $3,8 \%$, and it was 1,5 times more prevalent in boys $(4,5 \%)$ than in girls $(3,1 \%)$.

Wertzner and Oliveira (2002) studied 20 children with phonological disorder, 8 boys and 12 girls, and found that $15 \%$ of the subjects were under 4:00 years of age; $15 \%$ were between 4:00 and 4:11 years-old; $40 \%$ between 5:00 and 5:11 years-old; $20 \%$ between 6:00 and 6:11 years-old; and 20\% over 7:00 years of age. Papp (2003) found higher occurrence of phonological disorder in male subjects, with age varying between 5:00 and 7:00 years. The phonological disorder may have as causal factors: positive family history, hearing problems, otitis with efusion, and pré and peri-natal problems (Shriberg, 1999; Fox et al., 2002; Wertzner, 2002).

As demonstrated by the studies mentioned above, for a precise diagnosis, as well as for a better intervention planning, it is necessary to use severity indexes associated with the perceptual classification of the severity. Thus, the main purpose of the present research was to use the PCC's severity index, as well as to verify the correlation between this index and the the one perceptually applied by the judges.

\section{Method}

The research was accomplished in two parts. In a first moment the Phonology tests data were collected and analysed, and afterwards, the judges performed the perceptual judgement of the severity. The Research Projects Ethics Committee - CAPPesq of the Clinical Board of Hospital das Clínicas and the Medicine Faculty of University of São Paulo approved the first part (protocol 286/99) and the second part of the research (protocol 950/00). All parents or legal guardians of the participants signed the informed-consent.

\section{Subjects}

Fifty subjects from 4:00 to 11:00 years fo age, with phonological disorder diagnosed in the Laboratory of Speech and Hearing Pathologies Investigation of the University of São Paulo, took part in this research.

Sixty judges, graduation and post-graduation students of the Speech and Hearing Pathology Course, also participated: 12 judges from the $1 \mathrm{st}$ year of the Course (group J1); 12 judges from the 2nd year (group J2), 12 judges from the 3rd year (group J3); 12 judges from the 4th year (group J4); and 12 MSc students (group J5).

\section{Procedures}

After the diagnosis of the phonological disorder and the signing of the informed-consent, the phonology protocols of the Child Language Test ABFW (Wertzner, 2000) were used to calculate the Percentage of Correct Consonant index (PCC), proposed by Shriberg and Kwiatkowski (1982), with some adaptations for the Portuguese language indicated by Wertzner (2002).

Therefore, for the calculation of the PCC only the consonants that the child was intended to 
produce in the word must be considered. The consonants of repeted syllables in the word, and those occured in partial words, completelly inintelligibles or unclear, must not be accounted. The addition of a consonant before a vowel must not be calculated, once only consonants are being considered.

Chart 1 displays the types of changes in consonantal sounds considered as incorrect in this research. As Shriberg and Kwiatkowski (1982) stressed, for a child with speech errors, a correct sound must be accounted only when it was surely adequate produced. Therefore, questionable sounds must be classified as errors. The regional variations, allophones, and intentional junctions performed by the child must be considered as correct.

Chart 1. Productions considered as errors in PCC accounting.

\author{
eliminação da consoante \\ substituição da consoante por outra \\ sonorização ou ensurdecimento parcial da consoante \\ distorção do som não importa o quanto seja sutil; considera-se as distorções \\ comuns e incomuns \\ adição de um som a um padrão consonantal
}

To proceed with the PCC calculation, it is necessary to compute the consonants of the words that the child really produced. If the child fails to say any word, the consonants of this word must be deducted from the calculation. The categories of PCC determined by Shriberg and Kwiatkowski (1982) are: mild - over 85\%; mild-moderate - between $65 \%$ and $85 \%$; moderate-severe - from 50 to $65 \%$ and, severe below $50 \%$.

Afterwards, the video tapes with the phonology tests recordings were presented to the judges. The tapes were recorded with a digital video camera Sony CCD-TRV66 and were edited according to the selected presentation order. In order to watch the videos, the goups of judges were rearranged in 3 groups, each of them with 4 judges from J1, J2, J3, J4 and J5, totalizing 20 judges per group. The video presentation order was draft for each group, so that the same subject would not be presented in the same order for the 3 groups.

The subjects' video tapes were presented to the judge groups in three sessions of one hour and thirty minutes each, in order for them to indicate the severity degree of the disorders. Information about gender and age were given. After listening to the recordings, the judges filled out the protocol of severity degree for each subject, according to the following posibilities: mild, mild-moderate, moderate-severe, and severe.

The association between the variables was verified using the Spearman Correlation test and the Kappa test. The Kappa test measures the concordance between the variables (Kappa H"1, maximum concordance). The Spearman correlation test indicates the dependency between the variables. The intensity of associaation is given by the correlation coeficient.

In order to verify the equality of the judges responses for the severity judgement and for the intelligibility, the variance analysis of ANOVA was used with repeated measures in one factor (there is equality between the means if pd"0.050), and when it was observed inequalities between the means of the groups, the multiple comparisons of Bonferroni method were performed (there s equality if pd'0.050).

\section{Results}

Severity classification by PCC

Table 1 shows the desriptive values of the PCC index in the two phonology tests of the Child Language Test ABFW (Wertzner, 2000) and the value for the total of the two tests. In figures 1 and 2 it is possible to observe the number of subjects in each of the severity degrees proposed by Shriberg and Kwiatkowski (1982), and to verify that the subjects distribution regarding the severity degree was similar in the two tests.

Perceptual judgment of the severity

The judges of each group classified the severity of the subjects according to the requested degrees. Figure 3 shows the classification, considering the mode of the 60 judges' judgment.

Inferential analysis of the perceptual judgements of the speech severity of the 50 subjects were performed to verify the equality of the judges' responses.

In order to verify the equality of the responses given by the judges of the 5 groups, the variance analysis with repeated measures in one factor was used. A significance level of $5 \%$ allowed to conclude that there were evidences of difference 
between the 5 groups $(\mathrm{p}<0.001)$. In order to verify which groups differed, the multiple comparisons of Bonferroni method were performed (Table 2), and it was possible to observe that on average the $\mathrm{J} 1$ differed only from the $\mathrm{J} 4$. The $\mathrm{J} 2$ on average presented different responses than $\mathrm{J} 3, \mathrm{~J} 4$ and $\mathrm{J} 5$. The J3 judges on average classified the severity the same way as the J5, and differently than J4. Finally, the J4 and J5 on average didn't present the same responses in the classification of the severity.

Mean value of PCC according to the perceptual judgment of severity

Considering the subjects severity degree specified by the judges and the calculated value of PCC, it was obtained the mean PCC for the studied sample. It can be seen in table 3 the mean PCC for each judge group, and in table 4 , the mean value given by the 60 judges for the studied sample.

Association between the PCC index and the severity degree chosen by the judges

Figures 3 to 8 show the Box plot between the PCC and the perceptual judgment of the severity chosen by the judges. It can be observed that as the severity judgment increases, the PCC decreases in all groups of judges.

The Spearman Correlation test was used in order to verify the association between the PCC index and the perceptual judgment of the severity, considering the PCC values of the 50 subjects with phonological disorder and the mean scores of severity given by the judges of each group. Table 5 shows the values that indicate high negative correlation between the PCC and the severity judgment for all groups, with $\mathrm{p}<0.001$ in all situations. Thus, the higher the severity score given by the judges, the lower the PCC.

Agreement between the judges for the severity judgment was studied inter and intra-groups, using the Kappa test that measures the concordance between the variables (Kappa H'1, maximum concordance). The results are shown in tables 6 and 7 . It can be observed that in both situations the concordance was low.
TABLE 1. Descriptive statistica of PCC index applied in the imitation and naming tests.

\begin{tabular}{ccc|c|c} 
& Média & Desvio Padrão & Máximo & Mínimo \\
\hline imitação & 82 & 12 & 97 & 46 \\
nomeação & 81 & 13 & 98 & 40 \\
média das provas & 81 & 12 & 97 & 43
\end{tabular}

TABLE 2. Severity - multiple comparisons by Bonferroni method.

\begin{tabular}{ccc} 
& Grupo & Nível Descritivo (p) \\
1 & 2 & $>0,999$ \\
3 & $>0,999$ \\
4 & $<0,001$ \\
& 5 & 0,743 \\
& 3 & 0,015 \\
2 & 4 & $<0,001$ \\
& 5 & $<0,001$ \\
& 4 & $<0,001$ \\
& 5 & $>0,999$ \\
& 5 & $<0,001$ \\
\hline
\end{tabular}

TABLE 3. Mean PCC for each group of judges.

\begin{tabular}{cccccc} 
& \multicolumn{5}{c}{ PCC Médio (\%) } \\
grau atribuído & J1 & J2 & J3 & J4 & J5 \\
leve (1) & 83,8 & 83,9 & 82,8 & 85,3 & 84,2 \\
levemente moderado (2) & 82,5 & 81,9 & 81,8 & 73,3 & 81,5 \\
moderadamente severo (3) & 78,1 & 81,0 & 79,3 & 80,4 & 78,4 \\
severo (4) & 67,1 & 64,6 & 69,4 & 79,9 & 72,7 \\
\hline
\end{tabular}

TABLE 4. Mean PCC for the 60 judges.

$\begin{array}{cc}\text { Grau Atribuído } & \text { PCC Médio (\%) } \\ \text { leve (1) } & 84,0 \\ \text { levemente moderado (2) } & 80,2 \\ \text { moderadamente severo (3) } & 79,5 \\ \text { severo (4) } & 73,7\end{array}$

TABLE 5. Spearman correlation between the PCC and the perceptual judgment of the severity.

$\begin{array}{cc}\text { Juizes } & \text { Correlação } \\ \text { J1 } & -0,73 \\ \text { J2 } & -0,71 \\ \text { J3 } & -0,67 \\ \text { J4 } & -0,67 \\ \text { J5 } & -0,67\end{array}$


TABLE 6. Inter-group concordance for the severity.

\begin{tabular}{cc} 
Intergrupo & kappa \\
$\mathrm{J} 1$ e J2 & 0,168 \\
$\mathrm{~J} 1$ e J3 & 0,184 \\
$\mathrm{~J} 1$ e J4 & 0,168 \\
$\mathrm{~J} 1$ e J5 & 0,166 \\
$\mathrm{~J} 2$ e J3 & 0,167 \\
$\mathrm{~J} 2$ e J4 & 0,163 \\
$\mathrm{~J} 2$ e J5 & 0,158 \\
$\mathrm{~J} 3$ e J4 & 0,165 \\
J3 e J5 & 0,182 \\
J4 e J5 & 0,163 \\
todos os grupos & 0,163 \\
\hline
\end{tabular}

TABLE 7. Intra-group concordance for the severity.

Intragrupo
J1
J2
J3
J4
J5

Kappa
0,194
0,158
0,184
0,177
0,170

FIGURE 1. Subjects distribution according to the severity degree by PCC.

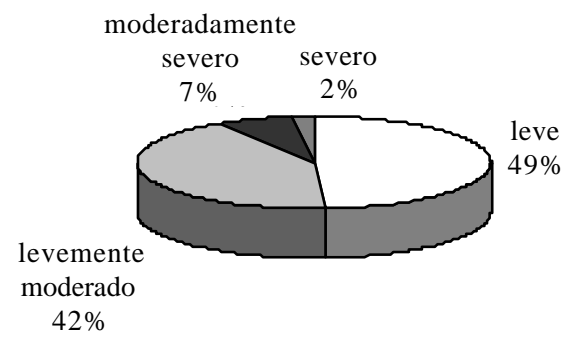

FIGURE 3. Box plot of PCC (\%) by the score modes given by the 60 judges.

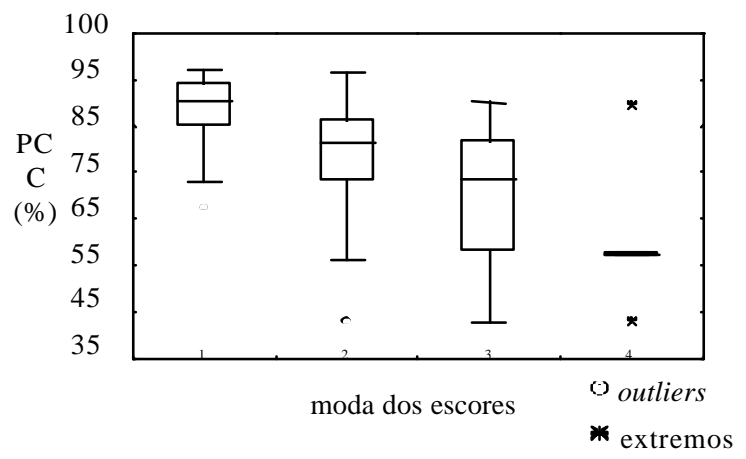

FIGURE 2. Perceptual judgement of the severity.

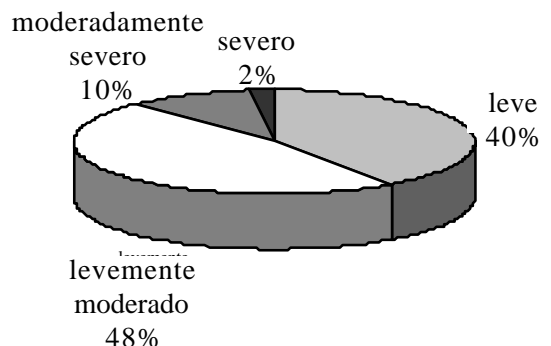

FIGURE 4. Box plot of PCC (\%) by the score modes given by the group of judges J1.

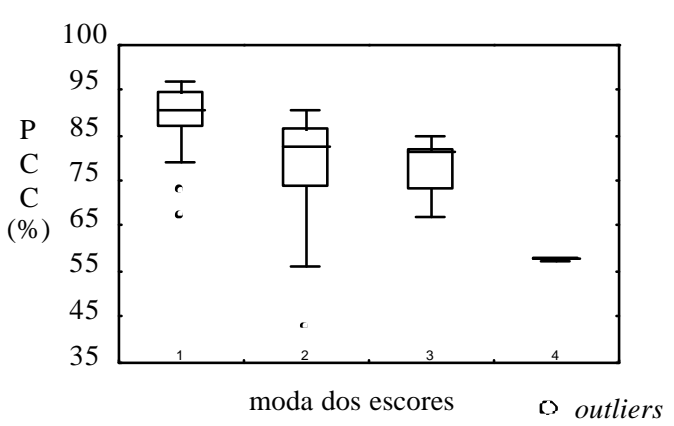


FIGURE 5. Box plot of PCC (\%) by the score modes given by the group of judges $\mathbf{J} 2$.

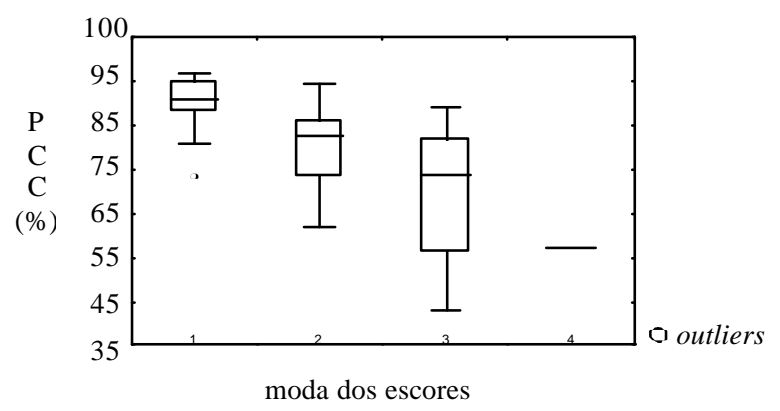

FIGURE 7. Box plot of PCC (\%) by the score modes given by the group of judges $\mathrm{J} 4$.

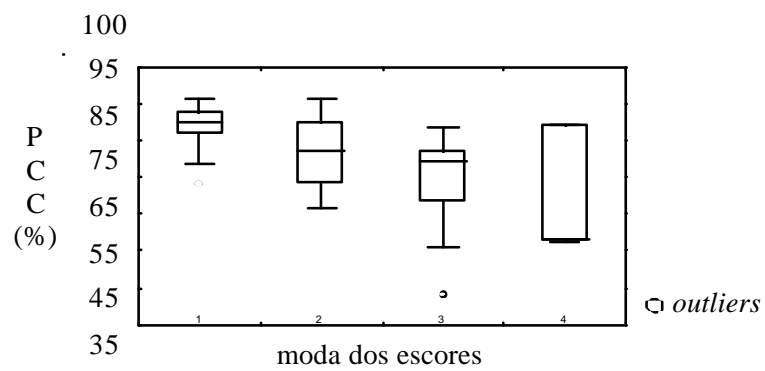

FIGURE 6. Box plot of PCC (\%) by the score modes given by the group of judges $\mathrm{J} 3$.

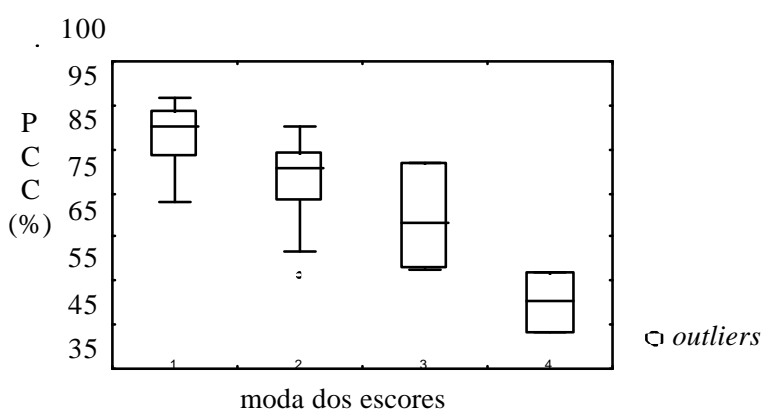

FIGURE 8 . Box plot of PCC (\%) by the score modes given by the group of judges $\mathrm{J} 5$.

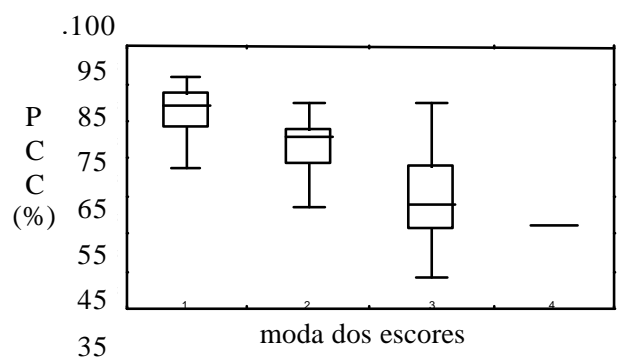

\section{Discussion}

The results showed that the PCC index (Shriberg and Kwiatkowski, 1982) applied to Brazilian Portuguese speaking subjects with phonological disorder had a variation between $40 \%$ and $98 \%$, with a predominant classification of the population in the mild and mild-moderate degrees. These data agree with the ones described for the English language, where the moderate-severe and severe degrees are less frequent in children with phonological disorder (Shriberg et al., 1986; Shriberg and Kwiatkowski, 1994).

Considering the study performed withBrazilian Portuguese speaking children, without complaint about the acquisition of the phonological system, Dias and Wertzner (2000) observed that, for 4:1 years-old children, the mean PCC was $91 \%$, and for 5:1 years-old children, the mean PCC was 93\%. Therefore, in the present research it was verified that children with phonological disorder were below the expected compared with children without phonological disorder.

Once the PCC index was studied in English speaking children and compared to the judgment of American speech pathologists, in this research, besides the application of the index, as showed above, it was observed how the Speech and Hearing Pathology Course graduation and Master students (J1, J2, J3, J4 e J5) classified the phonological disorder presented by the studied subjects.

According to the judgment of the 5 groups of judges, the classifications of mild-moderate, mild, moderate-severe and severe were registered, in descending order of subjects. Comparing the groups of judges, it was verified that, on average, the responses of the groups were different for the 
50 subjects. It was noted that this difference occurred for the group J4, comprising graduation students of the 4th year of the Speech and Hearing Pathology Course. This difference may be due to the fact that, at that moment, those students were beginning the training process on phonological disorder diagnosis and treatment, and were more rigorous and critic regarding the expectation of the subjects.

The correlation between the PCC values and the mean values of severity judgment of each group of judges was high. This showed that as the PCC value decreased, the severity degree given by the judges increased. This data indicates that the perceptual judgment of the judges may be used in the diagnosis of phonological disorders. Similar results were found by Shriberg and Kwiatkowski (1982) and Garret and Moran (1992).

The mean PCC of the subjects, according to the severity degree given by the judges, showed that for all groups, the mean PCCs of the mild and mild-moderate degrees were very close; the same happened with the moderate-severe and severe degrees. This may have occurred due to the difficulty to determine perceptually slight differences that are measured objectively. It is important to stress that, on average, the PCC values decreased regarding the increase of the severity degree given by the groups of judges, except the J4. The mean PCC for the 60 judges showed difference between the four severity degrees, although these values were very close and didn't demonstrate similarity with those presented by Shriberg and Kwiatkowski (1982).
Although the severity classification is valuable to guide the phonological disorder treatment, it is important to stress the relevance of the PCC severity index as a normalization marker of the phonological system presented by the subject with a disorder and used for the comparative control throughout the treatment (Wertzner et al., 2001; Pagan e Wertzner, 2002). It can also be emphasized that the PCC index and its variations (Shriberg et al., 1997; Shriberg, 1999; Shriberg et al. 2000 a and $2000 \mathrm{~b}$ ) are being used in the classification of the several subtypes of phonological disorder, independently of the adjectives that classify them.

As showed above, the perceptual judgment of the severity and the PCC presented correlation, pointing to the importance of the judgment by the speech pathologist. The intra-group concordance study for the perceptual judgment of the phonological disorder severity indicated that, although there is an association between the judgments, the concordance is weak, that is, not always judges from the same group have the same judgment criteria. The same was verified in the inter-group study. This low concordance between the judges denotes the necessity of the use of standardized indexes to indicate the degree associated to the severity classification.

\section{Conclusion}

This study revealed a correlation between the perceptual judgment of the judges and the PCC index. Thus, the PCC index use for the classification of the phonological disorder severity demonstrated to be a good instrument, either to assist in the diagnosis and to monitor the treatment.

\section{References}

BOWEN, C. Developmental phonological disorders: a practice al guide for families e teachers. Australia. Acer Press, 1998, 40 p.

DIAS, T. A.; WERTZNER, H. F. Descrição dos índices PCC e PDI para crianças de 3;00 a 5;6 anos sem queixa de distúrbio de comunicação. In: CONGRESSO BRASILEIRO DE FONOAUDIOLOGIA, 8., 2000, Recife. Resumos... São Paulo: [s.n.], 2000. p. 25.

EDWARDS. M. L. Clinical forum: phonological assessment and treatment in support of phonological processes. Lang. Speech Hear. Serv. Schools, v. 23, n. 3, p. 233-240, 1992.
FEY, M. E. Clinical forum: phonological assessment and treatment articulation and phonology: inextricable constructs in speech pathology. Lang. Speech Hear. Serv. Schools, v. 23, n. 3, p. 225-232, 1992.

FOX, A V.; DODD, B.; HOWARD, D. Risk factors for speech disorders in children. J. Lang. Com. Dis., v. 37 n. 2, p. 117-131, 2002 .

GARRET, K. K.; MORAN, M. J. A comparison of phonological severity measures. Lang. Speech Hear. Serv. Schools, v. 23, n. 1, p. 48-51, 1992. 
GIERUT, J. A. Treatment efficacy: functional phonological disorders in children. J. Speech, Lang. Hear. Res., v. 41 p. S85-S100, 1998.

HODSON, B. W.; PADEN, E. P. Phonological processes which characterize unintelligible and intelligible speech in early childhood. J. Speech Hear. Dis., v. 46, n. 4, p. 369373,1981 .

HODSON, B. W.; PADEN, E. P. Targeting intelligible speech: a phonological approach to remediation. 2. ed. Austin, Texas: Pró-ed, 1991. 190 p.

LAMPRECHT, R. R. A aquisição fonológica normal e com desvios fonológicos evolutivos: aspectos quanto à natureza da diferença. Letras de Hoje, v. 30 n. 4 p. 117-125, 1995.

MORRISON, J. A.; SHRIBERG, L. D. Articulation testing versus conversation speech sampling. J. Speech Hear. Res., v. 35 , n. 2 , p. $259-273,1992$

PAGAN, L. O.; WERTZNER, H. F. Intervenção no distúrbio fonológico através de pares mínimos com oposição máxima. Pró-Fono Revista de Atualização Científica, v. 14, n. 3, p. 313-324, 2002.

PAPP, A C. C. S. Um estudo sobre a relação do aspecto familial e o distúrbio fonológico. 2003. $110 \mathrm{f}$. (Mestrado em Semiótica e Lingüística Geral) - Faculdade de Filosofia, Letras e Ciências Humanas, Departamento de Linguística da Universidade de São Paulo, São Paulo.

PEÑA-BROOKS, A.; HEDGE, M. N. Assessment and treatment of articulation and phonological disorders in children. Austin: Pro Ed, 2000.

SHRIBERG, L. D. Epidemiologic and diagnostic profiles for five developmental phonological disorder. In SEMINAR PRESENTED AT THE ANNUAL CONVENTION OR THE AMERICAN SPEECHLANGUAGE-HEARING ASSOCIATION, 1999, San Francisco. November, 1999. Disponível em: <http:// www.waisman.wisc.edu/phonology>. Acesso em: dez. 2002. SHRIBERG, L. D.; AUSTIN, D.; LEWIS, B. A.; McSWEENY, J. L.; WILSON, D. L. The speech disorders classification system (SDCS): extensions and lifespan reference data. J. Speech Hear. Res., v. 40, n. 4, p. 723740,1997

SHRIBERG, L. D.; FLIPSEN, P. J.; THIELKE, H.; KWIATKOWSKI, J.; KERTOY, M. K.; KATCHER, M. L.; NELLIS, R. A.; BLOCK, M. G. Risk for speech disorder associated with early recurrent otitis media efusion: two retrospective studies. J. Speech Lang. Hear. Res., v. 43, n. 1, p. 79-99, 2000a.
SHRIBERG, L. D.; FRIEL-PATTI, S.; FLIPSEN, P. J.; BROWN, R. L.; Otitis media, fluctuant hearing loss, and speech-language outcomes: a preliminary structural equation model. J. Speech Lang. Hear. Res., v. 43, n. 1, p. 100-120, 2000 b.

SHRIBERG, L. D.; KWIATKOWSKI, J. Phonological disorders III: a procedure for assessing severity of involvement. J. Speech Hear. Dis., v. 47, n. 3, p. 256-270, 1982.

SHRIBERG, L. D.; KWIATKOWSKI, J. Development phonological disorders I: a clinical profile. J. Speech Hear. Res., v. 37, n. 5, p. 1100-1126, 1994.

SHRIBERG, L. D.; KWIATKOWSKI, J.; BEST, S. HENGST, J. Characteristics of children with phonological disorders of unknown origin. J. Speech Hear. Dis., v. 51, n. 2, p. $140-161,1986$

SHRIBERG, L. D.; TOMBLIN, J. B.; McSWEENY, J. L. Prevalence of speech delay in 6-year old children and comorbidity with language impairment. J. Speech Hear. Res., v. 42, n. 6, p. 1461-1481, 1999.

STOEL-GAMMON, C.; DUNN, C. Normal and disordered phonology in children. Austin: Pro-Ed, 1985.

WAGNER, R.; TORGESEN, J.; RASHOTTE, C. Comprehensive test of phonological processing (CTOPP). Austin: Pro ed, 1999.

WERTZNER, H. F. Fonologia. In: ANDRADE, C. R. F. de.; BEFI-LOPES, D. M.; FERNANDES, F. D. M.; WERTZNER, H. F. $A B F W$ : teste de linguagem infantil nas áreas de fonologia, vocabulário, fluência e pragmática. Barueri: Pró-Fono, 2000. cap. 1.

WERTZNER, H. F. O distúrbio fonológico em crianças falantes do português: descrição e medidas de severidade. 2002. Tese 228 f. (Livre-Docência Junto ao Departamento de Fisioterapia, Fonoaudiologia e Terapia Ocupacional) Faculdade de Medicina da Universidade de São Paulo, São Paulo.

WERTZNER, H. F.; HERRERO, S. F.; IDERIHA, P. N.; PIRES, S. C. F. Classificação do distúrbio fonológico por meio de duas medidas de análise: porcentagem de consoantes corretas (PCC) e índice de ocorrência dos processos (PDI). Pró-Fono Revista de Atualização Científica, v. 13, n. 1, p. 90-97, 2001.

WERTZNER, H. F.; GALEA, D. E. S., Porcentagem de consoantes corretas revisada (PCC-R) e índice de densidade fonológica (PDI) na aquisição fonológica. Rev. Soc. Bras. Fono., São Paulo, v. 7 n. 1 p. 44-50, 2002.

WERTZNER, H. F.; OLIVEIRA, M. M. F. Semelhanças entre os sujeitos com distúrbio fonológico. Pró-Fono Revista de Atualização Científica, v. 14, n. 2, p. 143-152, 2002.

Endereço para correspondência:

Haydée Fiszbein Wertzner

Av. Angélica, 566 apto. 61 - São Paulo - SP - CEP: 01280-000. 